\title{
Trade in the Golden Horde Volga Region
}

\author{
Leonard F. Nedashkovsky ${ }^{1}$ \\ ${ }^{1}$ Kazan (Volga Region) Federal University, Kazan, Russia \\ Correspondence: Leonard F. Nedashkovsky, Kazan (Volga Region) Federal University, 420008, Kazan, \\ Kremlyovskaya Street 18, Russia. E-mail: Leonard.Nedashkovsky@kpfu.ru
}

Received: June 15, 2015 Accepted: June 24, 2015 Online Published: June 30, 2015

doi:10.5539/jsd.v8n7p199 URL: http://dx.doi.org/10.5539/jsd.v8n7p199

\begin{abstract}
The research problem importance is determined by rather poor investigation of trade links in the Middle and Lower Volga region during the times of the Golden Horde; importance of the problem is also caused by the necessity to get the results for writing summarized works on Archaeology, History of trade and to use them during the creation of museum exhibitions and design of educational programs for undergraduate and post-graduate students. The article goal is to describe the leading fields of foreign trade in Lower Volga region as a part of Jochid state and the problems of domestic trade links at this land. The leading method for the problem research is the complex analysis of the data: written, archaeological and numismatic sources that allow get the most complete and realistic view of the trade links. The article is presenting the results that show significant rise of trade connections development in the Volga region of the researched period and the breadth of trade contacts and the peculiarities of inner trade. We also defined the features and the level of trade links development in the Volga region during the period of the Golden Horde. The article materials can be useful for research of the Golden Horde economy as well as the history of World Trade.
\end{abstract}

Keywords: the Golden Horde, the Volga region, foreign and domestic trade

\section{Introduction}

\subsection{Importance of the Problem}

The Golden Horde was one of the biggest states of the Middle Ages that existed in the second half of XIII - the second quarter of XV century. That period is characterized by the prosperity of cities and crafts caused by protectionism of khan power and by strong rise of trade: the region had highly developed agriculture production (Nedashkovskii, 2009; Nedashkovsky, 2014a) and special political institutions and social relationships (Fyodorov-Davydov, 1973). The Golden Horde power was notable for high level of monetary circulation, including the small retail trade. The research problem importance is stipulated by rather poor research of trade links of the Middle and Lower Volga region during the times of the Golden Horde (Nedashkovsky, 2012). Significance of the problem is also caused by the necessity to get the results to write summarized works on Archaeology, History of the trade as well as to use them during the creation of museum exhibitions and design of educational programs for undergraduate and post-graduate students.

\subsection{Status of the Problem}

The rise of trade links in the Volga region can be seen during the period of the Golden Horde. The materials of this research are closely connected with our characteristic of other fields of the Golden Horde economy: farming, cattle-breeding, trades (Nedashkovskii, 2009; Nedashkovsky, 2014a) and crafts (Nedashkovskii, 2009; Nedashkovsky, 2013).

\section{Methodological Framework}

\subsection{Objectives of the Study}

The article goal is to characterize the leading fields of foreign trade in the Lower Volga region as a part of Jochid state and the problems of domestic trade links at this land. On the basis of conducted research we have revealed that the Golden Horde cities of the Lower Volga region were closely connected with settled and nomadic neighbourhood through trade contacts and consequently it was incorporated into world trade system. 


\subsection{Theoretical and Methodological Basis of the Study}

The leading method for the problem research is the analysis of the data: written, archaeological and numismatic sources that allow consider the issues of foreign and domestic trade and get the most complete and realistic view of the trade links. The article is presenting the results that show significant rise of trade connections development in the Volga region of the researched period and the breadth of trade contacts and the peculiarities of inner trade. We also defined the features and the level of trade links development in the Volga region during the period of the Golden Horde.

\section{Results}

\subsection{Foreign Trade}

Trade links with India dated by the beginning of XIV century are proved by the information about goods (swords, flax and flax linen) brought from Russia to India. The information can be found in the works of the authors of the first half of XIV century - Amir Khusrau and al-Omari (Limonov, 1961; Zahoder, 1955). Export of horses from Kipchaks steppes to Indian lands had great significance in trade contacts with India (Tizengauzen, 1884). Sable and ermine skins were imported to India from the Golden Horde and were mostly bought by Bulgar merchants from the peoples of the North or received from the Russian territory. Some finds of golden coins of Delhi sultans, found in the Volga basin, are well known for research community (Fyodorov-Davydov, 2003). The majority of the Indian coins from the Golden Horde lands were found in the Volga Region. Along with the golden coins the raw ivory (found in the materials of Selitrennoe site) was brought from India; from the Indian ocean shore they brought cowries and corals; at Tsarevskoe site was found open-work bone plate that was decorated by the pictures of an elephant and monkey, the researchers propose its Indian origin (Fyodorov-Davydov, 2001).

Talc-chlorite vessels (mostly cauldrons) and grey-clay pottery were brought from Khorezm to the Volga region and they were found in the west up to Dnestr and Azak. By-turn pottery from the Volga region can be found in Khorezm and Usturt (Fyodorov-Davydov, 2001; Kdyrniyazov, 1978; Poluboyarinova, 2004; 2008; Volkov, 1992). The coins from Khorezm were involved in money circulation of the Volga region cities of the Golden Horde and the silks from Khorezm were delivered to the Volga region and then further to the West.

The Golden Horde silver coins of the Low Volga striking were found in Mongolia, in the Karakorum region (Voytov, 1990).

Silk and brocade fabrics, porcelain (found in the materials of Bolgarskoe and Tsarevskoe sites), Chinese bronze mirrors and the wares made of nephrite were delivered to the Volga region from China. The fragments of Chinese porcelain and even Korean celadon of XIV century have been found at Selitrennoe site (Fyodorov-Davydov, 2001; Fyodorov-Davydov \& Bulatov, 1989; Poluboyarinova, 1991; 2003a; 2003b; 2008).

Sturgeon, caviar, furs and salt were exported from the Volga region to the Black Sea and further to the Mediterranean Sea area and Italy (Emanov, 1995; Pegolotti, 1936). The Volga region ceramics of different kinds such as kashi, red-clay glazed ceramics, unglazed and stamped pottery was brought to Azak, Crimea, Northern Black Sea region and Balkans (Fyodorov-Davydov, 2001; Volkov, 1992). Venetian and Genoese merchants traded in the second half of XIII - XIV century in the Low Volga region and further to the east up to India and China (Emanov, 1995; Fyodorov-Davydov, 2001; Karpov, 2000).

The fragments of Trebizond, Triliya, Crimean and Azak amphorae and amphorae-like jars that were found at the monuments of the Low and Middle Volga regions prove that the Golden Horde imported wine and oil; the fragments of presumably Crete pithoses and the Black Sea region glazed pottery were found in the studied region also (Bulatov, 1969; Fyodorov-Davydov, 2001; Koval', 2003; Nedashkovsky, 2000; 2004; Poluboyarinova, 2008; Volkov, 2001). Western European cloth and flax linen also were brought to the Volga region. Western European bone statuette depicted a lying lion has been found at Uvek site; the bronze frame or the handle of the vessel of Mediterranean origin has been found at Vodyanskoe site; bronze wash-stands of XIII-XV centuries got through the territory of the Volga region from Western Europe to Siberia and bronze statuette of a knight of the French work got to Kazakhstan (Fyodorov-Davydov, 2001). Venetian ducat of XIV century was found near Astrakhan (Fyodorov-Davydov, 2003); a gold florin of 1329 was found in Bulgar in 1863 (Singatullina, 2009). In Karatun hoard Trebizond coin and Prague grosh were found (Fyodorov-Davydov, 2003). A copper coin of Trebizond Emperor Michael III (1341-1349) was found at Vodyanskoe site (Lebedev \& Klokov, 2005).

Connections of the Golden Horde Volga region with Byzantium are being confirmed by copper coin of the Emperors Andronicus II and Michael IX Palaeologus (1295-1320) found at Bolgarskoe site and the yperperon of 
Andronicus II (1282-1332) found at the settlement of Samosdelka in the Astrakhan region (Fyodorov-Davydov, 1987; Goncharov, 2003).

Glass lamps with painted enamel of different colours, and other glass vessels, as well as some types of kashi ceramics were brought from the Near East to the Middle and Lower Volga region; probably the marble candlestick with Arabic inscriptions found on Tsarevskoe site has Egyptian origin (Busyatskaya, 1972; 1976; Fyodorov-Davydov, 2001; Fyodorov-Davydov, Vayner \& Mukhamadiev, 1970; Koval', 2003; Poluboyarinova, 1988; 2008). Copper coin of Egyptian sultan from the Mameluke dynasty al-Mu'izz Izz ad-Din Aybak (1250-1257) was found in Dzhuketau (Lebedev, Bugarchev \& Gumayunov, 2008). Cairo dinar of Egyptian sultan al-Malik az-Zahir Rukn-ad-Din Baybars I al-Bundukdari (1260-1277) was found in one of the graves near the village Komsomol'sky of Krasnoyarsk area of Astrakhan region (Fyodorov-Davydov, 2001; 2003; Pavlenko, 2001). Damascus dinar of Mameluke dynasty (771 year A.H.) was found at Selitrennoe site (Lebedev \& Klokov, 2005). Artistic brass vessels with gold and silver inlay and expensive silk and brocade fabrics from the Near and Middle East were delivered to the Middle and Lower Volga region.

Finds of the Iranian kashi vessels at the Bolgarskoe site, and in the Lower Volga region fragments of Iranian ceramics such as 'minai' type and luster-painted vessels prove the trade contacts with Iran; red-clay glazed ceramics came from the Transcaucasia to the Volga region (Fyodorov-Davydov, 2001; Koval', 2003; Poluboyarinova, 2008; Volkov, 2000b). Silk and brocade, as well as, probably, cotton fabrics were brought from Iran.

Coins of Hulaguids, Jelairids, Timurids and Jagataids were found at the monuments of the Middle and Lower Volga, and in the hoards of these regions. Mostly the coins of Hulaguids, Jelairids and Timurids have been found in big hoards that can be connected with a merchant capital (Nedashkovsky, 2001).

In the Transcaucasia, in turn, silver and copper coins of Jochid khans, from Uzbek to Kildibek, of the Volga region striking were found (Fyodorov-Davydov, 1963). Silver coins of the Golden Horde mintage were found in the Transcaucasian hoards also (Fyodorov-Davydov, 1960; 2003).

The trade of North-East Russia with the East took place through the Volga. Ibn abd-az-Zahir wrote about the Volga river in connection with the visit of the ambassadors of the Mameluke sultan to the khan Berke to the Lower Volga region in 1263: 'The ships of Russians float on it' (Tizengauzen, 1884). Khorezm stone cauldrons, rings of glass, glass and kashi beads, unglazed, glazed and stamped the Golden Horde ceramics found during the excavations in many Russian cities up to Novgorod and Beloozero, were delivered to Rus from the Golden Horde (Dubynin, 1956; Fyodorov-Davydov, 2001; Golubeva, 1973; Kolyzin, 2001; Koval', 1995; 1997a; 1997b; 1997c; 2003; Medvedev, 1963; Mongayt, 1948; 1961; Poluboyarinova, 1978; 1993; Rybina, 1978; 2001). Cornelian, rock crystal, lazurite were brought through the Middle and Lower Volga region to Rus (Fyodorov-Davydov, 2001; Rybina, 1978; 2001) as well as the Iranian, Syrian, Central Asian and Transcaucasian glazed ceramics (Kolyzin, 2001; Koval, 1996; 1997a; 1997b; 2003), Chinese celadon wares (Fyodorov-Davydov, 2001; Kolyzin, 2001; Koval, 1997a; 1997c; Poluboyarinova, 2003a) and the Middle East glass vessels (Busyatskaya, 1972; Kolyzin, 2001; Stolyarova, 1997). In the Novgorod birch bark document of the border of the XIV and XV centuries the Middle Asian cotton fabric called "zenden" has been mentioned (Artsikhovsky, 1969). The hoards of the Golden Horde coins were found in Moscow and Nizhny Novgorod lands (Fyodorov-Davydov, 1960; 2003; Kolyzin 2001; Volkov, 2005b; Zaytsev \& Kolyzin, 2005). Separate Jochid dirhems and puls have been found on the territories of Moscow, Tver, Suzdal - Nizhny Novgorod principalities (Fyodorov-Davydov, 1963; Kolyzin 2001; Volkov, 2005a; 2005b). Glass bracelets and amber were delivered to Middle and Lower Volga region from Russian lands. Russian dengas can be often found as an impurity $(0.1 \%$ to $13.4 \%)$ in the Golden Horde hoards of the Volga region; judging by the size of the hoards containing Russian coins, these complexes are probably the savings of merchants, who traded in Rus (Fyodorov-Davydov, 1960; 1963; 1974; 2003; Kolyzin, 2001; Trost'yansky, 2008; Volkov, 2000a). At Selitrennoe site was found the hoard containing more than 3 thousands silver coins, including, in addition to Old Russian dengas, only 5 Golden Horde dirhems of the XV century (Trost'yansky, 2004; 2005). Russian coins can be also found at the settlements of the Middle and Lower Volga region (Goncharov \& Trost'yansky, 2004; Lebedev \& Klokov, 2005; Nedashkovsky, 2000; Trost'yansky, 2008); at Rozhdestveno V settlement in 2005, in addition to the published exemplars, the anonymous denga of Suzdal mintage (1427-1429) was found.

Internecine wars of 1360th-1370th broke the trade in the Volga region. At the end of the XIV century the most important cities of the Golden Horde were in decline or ceased to exist as a result of Timur's campaigns against the Golden Horde. The main trade routes between East and West has shifted towards the south and stopped to pass through the territory of the Ulus Jochi. 
But trade in Saray even in the XV century brought considerable income to foreign merchants. The saved report of Shams ad-Din Muhammad one of the merchant from Shiraz is showing that he sold his goods in Saray in 1438 and purchased there Chinese raw silk, silk damask, satin, European cloth and Russian flax linen (Zahoder, 1955).

Thus, in the Golden Horde period trade relations of the Volga region were flourished. Geography of contacts is very wide - Rus, Western and Central Europe, the Black Sea and the Mediterranean Sea regions, the Middle and Near East, Central and Middle Asia, India, China and Korea.

\subsection{Domestic Trade}

The basis of the inner trade of the Volga region of Jochid state were close links of the cities with small towns and rural settlements of their regions, trade relations with other regions of the Golden Horde and the contacts of sedentary and nomadic populations that shared the products of crafts and agriculture, on the one hand, and cattle-breeding - on the other. Domestic trade was based on a highly developed monetary circulation that met the needs of the big and small-scale retail trades.

Cities exchanged the high-tech products (glazed ceramics, glassware, cast-iron and many types of wares from non-ferrous metals) for the products of agriculture and trades delivered to the city from rural settlements; small urban and rural settlements lacked high-tech products. Simple forms of non-ferrous metals elaboration, of course, existed in small towns and rural settlements that is confirmed by the findings of metal splashes and scraps of metal at the settlements Bagaevka, Kolotov Buerak, Sovetskoe and Hmelevskoe I in the region of Uvek site as well as at Vodyanskoe site, where moulds were found (the only case of their finds outside the large cities). The Golden Horde unglazed pottery was also delivered from the cities to the countryside. The bulk of forging wares found at the rural settlements we also have to recognize as the production of urban craft.

It is through the cities as the big centres of international trade (from the urban monuments came all separate finds of foreign coins in the Lower Volga as well as the bulk of imports and wares imported from other regions) the villages received imported goods: wine in amphorae, brocade and silk fabrics, sometimes even luster ceramics and glass vessels with polychrome decorations. Finds of fragments of Trebizond amphorae are known from the settlements of Bagaevka (fragments of Triliya amphorae were also found there), Kolotov Buerak, Hmelevskoe I and Shiroky Buerak in the region of Ukek. Fragments of luster and painted glass vessels have been found during our excavations of Bagaevka settlement.

A variety of crafts (pottery manufacturing, glassmaking, cast-iron production, advanced forms of non-ferrous metals processing) could not exist in a nomadic way of life, therefore, all their products found in the burial monuments of nomads should be considered imported, delivered from the settlements of the Lower Volga region. Getting livestock and dairy products from the nomads, the city supplied them by crafts wares. Imported goods, in particular, wine in the amphorae, brocade and silk were also delivered for nomads.

Economic links were carried out not only through the direct exchange of food and raw materials for crafts wares, but to a greater extent by the commodity-money relations; this is confirmed by numerous finds of both silver and copper coins of the Golden Horde on many rural settlements and in the burial mounds of nomads.

\section{Discussions}

The problem of trade links of the Volga Region during the period of the Golden Horde is presented in a short chapter of the book written by G.A.Fyodorov-Davydov (Fyodorov-Davydov, 2001) only, where we can find the material about the trade in Jochid state but the author involved little materials from the Volga region, he did not studied the problems of domestic trade, pointed on less directions of trade connections and did not take into account some categories of marketing.

\section{Conclusion}

Researched materials allow to understand the peculiarity of economical interaction of the Golden horde city with its regions based on the exchange of the products of crafts, farming, cattle-breeding, trades and goods got by the means of distant international trade.

Rural regions of the Golden horde cities of the Lower Volga Region had well-developed agriculture and trades that could partly provide the cities by food and raw materials. The villages were provided through the cities by crafts products (glazed and unglazed ceramics, glass and cast-iron wares, goods from ferrous and non-ferrous metals) and expensive imported goods (wine, brocade and silk).

Nomads changed the products of cattle-breeding and got many craft goods most of which were made in the cities especially for them taking into account nomads' traditions and art demands (vessels, bone ornamented facings of 
quivers and some sorts of mirrors) (Nedashkovsky, 2014b). They also got imported goods that were also delivered to rural settlements.

It is evident that the Golden Horde cities of the Low Volga region were closely connected by the contacts of domestic trade (based on commodity-money relations) with the settled and nomadic periphery.

\section{Recommendations}

The article materials can be useful for research of the Golden Horde economy as well as the History of World Trade.

\section{Acknowledgement}

The work is performed according to the Russian Government Program of Competitive Growth of Kazan Federal University.

\section{References}

Artsikhovsky, A. V. (1969). Odezhda. Ocherky russkoi kultury XIII-XV vekov. Chast I. Materialnaya kultura (pp. 277-296). Moscow.

Bulatov, N. M. (1969). K voprosy o stanovlenii keramicheskogo remesla v zolotoordynskih gorodah. Vestnik $M G U$, ser. istoriya, 2, 46-59.

Busyatskaya, N. N. (1972). Khudozhestvennoye steklo stran Blizhnego Vostoka na territorii Vostochnoy Evropy (X-XIV vv.). Vestnik $M G U$, ser. IX istoriya, 2, 83-90.

Busyatskaya, N. N. (1976). Steklyannye izdeliya gorodov Povolzhya (XIII-XIV vv.). Srednvekovye pamayatniki Povolzhya (pp. 38-72). Moscow.

Dubynin, A. F. (1956). Arheologicheskie issledovaniya v Zaryad'e (Moskva). Kratkie soobshcheniya o dokladah i polevyh issledovaniyah Instituta istorii material'noy kul'tury AN SSSR, 65, 119-130.

Emanov, A. G. (1995). Sever i Yug v istorii kommertsii: Na materialah Kafy XIII-XV vv. Tyumen.

Fyodorov-Davydov, G. A. (1960). Klady dzhuchidskih monet. Numizmatika i epigrafika, I, 94-192.

Fyodorov-Davydov, G. A. (1963). Nahodki dzhuchidskih monet. Numizmatika i epigrafika, IV, 165-221.

Fyodorov-Davydov, G. A. (1973). Obshchestvennyy stroy Zolotoy Ordy. Moscow.

Fyodorov-Davydov, G. A. (1974). Nahodki kladov zolotoordynskih monet. Goroda Povolzh'ya v srednie veka (pp. 176-182). Moscow.

Fyodorov-Davydov, G. A. (1987). Denezhnoe delo i denezhnoe obrashchenie Bolgara. Gorod Bolgar. Ocherki istorii i kul'tury (pp. 158-204). Moscow.

Fyodorov-Davydov, G. A. (2001). Zolotoordynskie goroda Povolzh'ya: Keramika. Torgovlya. Byt. Moscow.

Fyodorov-Davydov, G. A. (2003). Denezhnoe delo Zolotoy Ordy. Moscow. http://dx.doi.org/10.1023/A:1022141317782

Fyodorov-Davydov, G. A., \& Bulatov, N. M. (1989). Keramicheskaya masterskaya Selitrennogo gorodishcha. Sokrovishcha sarmatskih vozhdey i drevnie goroda Povolzh'ya (pp. 133-248). Moscow.

Fyodorov-Davydov, G. A., Vayner, I. S., \& Mukhamadiev A. G. (1970). Arheologicheskie issledovaniya Tsarevskogo gorodishcha (Novyy Saray) v 1959-1966 gg. Povolzh'e v srednie veka (pp. 68-171). Moscow.

Golubeva, L. A. (1973). Ves'i slavyane na Belom ozere. X-XIII vv. Moscow.

Goncharov, E. Yu. (2003). Analiz monetnogo materiala s dvuh zolotoordynskih gorodishch. Drevnosti, 36. Arheologicheskie issledovaniya i muzeyno-kraevedcheskaya rabota v Volgo-Ural'skom regione, 239-242.

Goncharov, E. Yu., \& Trost'yansky, O. V. (2004). Monetny komplex XV v. iz sela Rozhdestveno. Dvenadtsataya vserossiyskaya numizmaticheskaya conferentsiya. Moskva, $19-24$ aprelya 2004 g. Tez. dokl. i soobshcheniy (pp. 94-95). Moscow.

Karpov, S. P. (2000). Ot Tany - v Urgench: eti trudnye dorogi srednevekov'ya. Srednie Veka, 61, 217-224.

Kdyrniyazov, M. Sh. (1978). Torgovye svyazi srednevekovyh gorodov Khorezma (XIII-XIV vv.). Vestnik Karakalpakskogo filiala Akademii nauk Uzbekskoy SSR, 3(73), 60-65.

Kolyzin, A. M. (2001). Torgovlya drevney Moskvy (XII - seredina XV v.). Moscow. 
Koval', V. Yu. (1995). Lyustrovaya keramika Blizhnego i Srednego Vostoka iz raskopok v Velikom Novgorode. Novgorod i Novgorodskaya zemlya. Istoriya i arheologiya, 9, 169-181.

Koval', V. Yu. (1996). Iranskaya lyustrovaya keramika v srednevekovoy Rusi. Tver', Tverskaya zemlya $i$ sopredel'nye territorii v epohu srednevekov'ya, 1, 235-240.

Koval', V. Yu. (1997a). Vostochnaya keramika zolotoordynskoy epohi v srednevekovom Novgorode. Novgorod i Novgorodskaya zemlya. Istoriya i arheologiya, 11, 153-166.

Koval', V. Yu. (1997b). Keramika Vostoka v srednevekovoy Moskve (opyt sistematizatsii). Chast' I. Fayansy i polufayansy. Rossiyskaya arheologiya, 2,104-122.

Koval', V. Yu. (1997c). Keramika Vostoka v srednevekovoy Moskve (opyt sistematizatsii). Chast' II. Polumajolika, farfor, nepolivnaya posudnaya, tehnicheskaya, dekorativnaya i arhitecturnaya keramika. Rossiyskaya arheologiya, 3, 94-113.

Koval', V. Yu. (2003). Glazurovannaya keramika iz okrestnostey Uveka. Kratkie soobshcheniya o dokladah $i$ polevyh issledovaniyah Instituta arheologii, 215, 58-69.

Lebedev, V. P., \& Klokov, V. B. (2005). Inozemnye monety XII-XV vv. na zolotoordynskih gorodishchah Povolzh'ya. Trudy mezhdunarodnyh numizmaticheskih conferentsiy. Monety $i$ denezhnoe obrashchenie $v$ mongol'skih gosudarstvah XIII-XV vekov. Saratov 2001, Murom 2003 (pp. 57-61).

Lebedev, V. P., Bugarchev, A. I., \& Gumayunov, S. V. (2008). Monetnoe obrashchenie Dzhuketau po numizmaticheskim dannym. Trudy mezhdunarodnyh numizmaticheskih konferentsiy. Monety i denezhnoe obrashchenie v mongol'skih gosudarstvah XIII-XV vekov. Bolgar 2005, Volgograd 2006 (pp. 39-49). Moscow.

Limonov, Yu. A. (1961). Iz istorii vostochnoy torgovli Vladimiro-Suzdal'skogo knyazhestva. Mezhdunarodnye svyazi Rossii do XVII v. (pp. 55-63). Moscow.

Medvedev, A. F. (1963). Blizhnevostochnaya i zolotoordynskaya polivnaya keramika iz raskopok v Novgorode. Materialy i issledovaniya po arheologii SSSR, 117, 269-286.

Mongayt, A. L. (1948). Zolotoordynskaya chasha iz Novgoroda Velikogo. Kratkie soobshcheniya o dokladah $i$ polevyh issledovaniyah Instituta istorii material'noy kul'tury AN SSSR, XIX, 70-73.

Mongayt, A. L. (1961). Ryazanskaya zemlya. Moscow.

Nedashkovskii, L. F. (2009). Economy of the Golden Horde population. Anthropology \& Archaeology of Eurasia, 48(2), 35-50. http://dx.doi.org/10.2753/AAE1061-1959480203

Nedashkovsky, L. F. (2000). Zolotoordynskiy gorod Ukek i ego okruga. M.: Izdatel'skaya firma "Vostochnaya literatura" RAN.

Nedashkovsky, L. F. (2001). Monety yuzhnyh sosedey Zolotoy Ordy v sobranii Saratovskogo oblastnogo muzeya kraevedeniya. Rossiya i Iran: Iranistika v Tatarstane (pp. 156-162). Moscow.

Nedashkovsky, L. F. (2004). Ukek: The Golden Horde city and its periphery / BAR. International Series, 1222. Oxford: Archaeopress.

Nedashkovsky, L. F. (2012). Golden Horde Antiquities: The development of research ideas. Acta Archaeologica, 83(1), 225-255. http://dx.doi.org/10.1111/j.1600-0390.2012.00690.x

Nedashkovsky, L. F. (2013). Remeslo Zolotoy Ordy. Problemy istorii, philologii, kul'tury, 3, 136-154.

Nedashkovsky, L. F. (2014a). Agriculture, Cattle Breeding and Trade in the Golden Horde Based on Data from Written Sources. Terra Sebus: Acta Musei Sabesiensis, Special Issue. Russian Studies. From the early Middle Ages to the present day, 291-303.

Nedashkovsky, L. F. (2014b). Struktura i vnutrennie svyazi okrugi zolotoordynskih gorodov Nizhnego Povolzh'ya. Rossiyskaya arheologiya, 2, 48-61.

Pavlenko, Yu. A. (2001). K voprosu o rasprostranenii sufizma v Nizhnem Povolzh’ye. Arheologiya Nizhnego Povolzh'ya na rubezhe tysyacheletiy: Materialy Vserossiyskoi nauchno-prakticheskoy konferentsii (pp. 74-76). Astrahan.

Pegolotti, F. B. (1936). La pratica della mercatura / Edited by A.Evans. Cambridge, Massachusetts: The Medieval Academy of America.

Poluboyarinova, M. D. (1978). Russkie lyudi v Zolotoy Orde. Moscow. 
Poluboyarinova, M. D. (1988). Steklyannye izdeliya Bolgarskogo gorodishcha. Gorod Bolgar: Ocherki remeslennoy deyatel'nosti (pp. 151-219). Moscow.

Poluboyarinova, M. D. (1991). Ukrasheniya iz tsvetnyh kamney Bolgara i Zolotoy Ordy. Moscow.

Poluboyarinova, M. D. (1993). Rus i Volzhskaya Bolgariya $v$ X-XV vv. Moscow.

Poluboyarinova, M. D. (2003a). Kitayskiy seladon iz Bolgara. Rossiyskaya arheologiya, 2, 155-164.

Poluboyarinova, M. D. (2003b). Kitayskiy farfor s Bolgarskogo gorodishcha. Rossiyskaya arheologiya, 3, 136-144.

Poluboyarinova, M. D. (2004). Kamennye kotly iz Bolgara. Vostochnaya Evropa v srednevekov'e. K 80-letiyu Valentina Vasil'evicha Sedova (pp. 316-323). Moscow.

Poluboyarinova, M. D. (2008). Torgovlya Bolgara. Gorod Bolgar: kul'tura, iskusstvo, torgovlya (pp. 27-107). Moscow.

Rybina, E. A. (1978). Arheologicheskie ocherki istorii novgorodskoy torgovli X-XIV vv. M.: Izd-vo Mosk. un-ta.

Rybina, E. A. (2001). Torgovlya srednevekovogo Novgoroda. Istoriko-arheologicheskie ocherki. Velikiy Novgorod: Izdatel'sko-poligraficheskiy tsentr Novgorodskogo gos. un-ta im. Yaroslava Mudrogo.

Singatullina, A. Z. (2009). O nekotoryh zolotyh monetah iz sobraniya Natsional'nogo muzeya, naydennyh na territorii Respubliki Tatarstan. Srednevekovaya arheologiya Povolzh'ya: materialy i issledovaniya po arheologii Povolzh'ya, 4, 78-97.

Stolyarova, E. K. (1997). Proishozhdenie i hronologiya steklyannyh izdeliy Moskvy XII-XIV v. Rossiyskaya arheologiya, 4, 93-106.

Tizengauzen, V. G. (1884). Sbornik materialov, otnosyashchihsya k istorii Zolotoy Ordy. SPb.: Tip. imp. AN. T. I / Izvlecheniya iz sochineniy arabskih.

Trost'yansky, O. V. (2004). Klad suzdal'sko-nizhegorodskih monet XV veka s Selitrennogo gorogishchsa. Drevnosti Povolzh'ya i drugih regionov, 4, V, 237-268.

Trost'yansky, O. V. (2005). Monety nizhegorodskogo knyazya Ivana Vasil'evicha. Trinadtsataya Vserossiyskaya numizmaticheskaya konferentsiya. Moskva, 11-15 aprelya $2005 \mathrm{~g}$. Tez. dokl. i soobshcheniy (pp. 117-120). Moscow.

Trost'yansky, O. V. (2008). "Voennye dengi" knyazya Yuriya Dmitrievicha. Trudy mezhdunarodnyh numizmaticheskih konferentsiy. Monety $i$ denezhnoe obrashchenie $v$ mongol'skih gosudarstvah XIII-XV vekov. Bolgar 2005, Volgograd 2006 (pp. 76-78). Moscow.

Volkov, I. V. (1992). Keramika Azova XIV-XVIII vv. (Klassifikatsiya i datirovka): avtoref. dis.: ...kand. ist. nauk. Moscow.

Volkov, I. V. (2000a). Russkie monety v kladakh Povolzhya posledney chetverti XIV - pervoy chetverti XV v. Vos'maya vserossiyskaya numizmaticheskaya konferentsiya. Moskva, 17-21 aprelya $2000 \mathrm{~g}$. Tez. docl. $i$ soobshcheniy (pp. 80-82). Moscow.

Volkov, I. V. (2000b). Shirvansky keramicheskiy import v zolotoordynskikh gorodakh. Srednyaya Aziya: Arheologiya, istoriya, kul'tura. Materialy mezhdunarodnoy konferentsii, posvyashchyonnoy 50-letiyu nauchnoy deyatel'nosti G.V.Shishkinoy. Gosudarstvennyy muzey Vostoka, 14-16 dekabrya 2000 g. (pp. 45-50). Moscow.

Volkov, I. V. (2001). Zolotaya Orda i hristianskiy mir (arheologicheskie svidetel'stva istoricheskih yavleniy). Vestnik Rossiyskogo gumanitarnogo nauchnogo fonda, 4, 15-25.

Volkov, I. V. (2005a). Komplex srednevekovyh monet s poseleniya u d. Gorodishchi-Yushkovo Moskovskoy oblasti. Trinadtsataya Vserossiyskaya numizmaticheskaya konferentsiya. Moskva, 11-15 aprelya $2005 \mathrm{~g}$. Tez. dokl. i soobshcheniy (pp. 108-109). Moscow.

Volkov, I. V. (2005b). Ob obrashchenii dzhuchidskogo dirhema v moskovskih zemlyah vo vtoroy polovine XIV - nachale XV vv. Trudy mezhdunarodnyh numizmaticheskih konferentsiy. Monety i denezhnoe obrashshenie v mongol'skih gosudarstvah XIII-XV vekov. Saratov 2001, Murom 2003 (pp. 62-67). Moscow.

Voytov, V. E. (1990). Mogilniki Karakoruma (po materialam rabot 1976-1981 gg.). Arkheologicheskie, etnographicheskie i antropologicheskie issledovaniya v Mongolii (pp. 132-149). Novosibirsk.

Zahoder, B. N. (1955). Shirazskiy kupets na Povolzh'e v 1438 g. (K voprosy o russkih economicheskih svyazyah 
s Sibir'yu, Sredney Aziey i Perednim Vostokom). Kratkie soobshcheniya Instituta vostokovedeniya, XIV, 14-19.

Zaytsev, V. V., \& Kolyzin, A. M. (2005). Dva klada zolotoordynskih monet. Trinadtsataya Vserossiyskaya numizmaticheskaya conferentsiya. Moskva, 11-15 aprelya 2005 g. Tez. dokl. i soobshcheniy (pp. 53-54). Moscow.

\section{Copyrights}

Copyright for this article is retained by the author(s), with first publication rights granted to the journal.

This is an open-access article distributed under the terms and conditions of the Creative Commons Attribution license (http://creativecommons.org/licenses/by/3.0/). 